\title{
Assessing the Components of Mentoring In Nursing Practice Placements. A Mixed Study Approach.
}

\author{
Victor Etu Tanyi. \\ Bsc RN B.Ed.
}

\begin{abstract}
This study is based on assessing the components of mentoring aiming at identifying ways in improving the quality of mentor/mentee dyads.

Design: Qualitative and Quantitative design.

Sample Type: Simple random sampling, cluster sampling, and purposeful sampling.

Results: The key components of mentoring are important in the mentor/mentee dyads. Cultural competency is vital in a mentoring relationship. Making use of evidence-based principles by the mentors is essential to instil the culture of best practice in the mentee. Structured learning is an essential compliment for modelling.

Conclusion: Adhering to the values deriving from the components of mentoring will be beneficial to both the mentors and mentees and will not only improve the quality of learning but also skills and potential to develop into the career.

Recommendation: A more extensive studies to be carried with a larger sampling size and complex quantitative analysis to determine the extent to which mentoring components and associative themes as cultural competency and evidenced-based practice can influence the mentee/protégé dyads.
\end{abstract}

\section{Background of Study}

The focus of this study will be on the assessment of the various key components of mentoring relationships and examine its benefits in order to evaluate the nursing education as a whole, limiting the study on the learning process whilst on practice placement.

Student nurses are often evaluated following a set of skills demonstrated whilst on placement but these skills are often generic, outlined in student University manuals to be applied to all the mentees regardless of whichever ward they are allocated. The concerns here may be that some specific ward base skills may not be learned or achieved especially in a situation where the mentee/mentor dyads are authoritarian.

The learning environment for nurses and student nurses is multi-disciplinary and evaluating the performance of a student nurse may go beyond the level of the mentor. In an ideal clinical setting in order to render therapeutic services, students may interact with the patient, nurses, care assistants, physiotherapist, medical doctors, janitors, kitchen staff and other allied health professionals. In as much as the service is within the level of competency, a student nurse is expected to work in accordance with ward policy. The bar is often raised too high in a clinical setting and even if a skill is not specified in the student manual but is still required for patient care, it is expected of a student to maintain high standards in delivering care. An example would be a hospital caterer expecting a student to make a toasted bread just as good as the caterer would do. However a student nurse is expected to make a toast for the patients in times of need, but the question remains if catering skills are specified in the learning manual or are just life skills needed for nursing. Holistic assessment has proven worthy but there must be a measure based on evidence when considering the opinion of other members of staff.

There is no doubt that learning and assessment are achieved in each practice placement regardless of which mentoring style utilised, but there might be concerns that best practice may be jeopardised, (Brown,2008) when evidenced-based practices are not incorporated into the mentoring process. This is driven by a multitude of complexities that comes with mentoring, such as alternative forms of mentoring, diverse cultures, mentoring context, conceptualisation, and diversities in best practice (Brondyk and Searby 2013). The Department of Health DH and Public Health England PHE, have set guidelines regulating best practices in the National Health Service NHS and also private health institutions. This is to ensure that evidenced-based practices are utilised regularly on a day to day practice, the service needs of institutions and programmes aimed at meeting the needs are in place and supported locally (DH and PHE, 2013).

It is expected that each student is given equal opportunities whilst at placement, but with the varying forms of mentoring styles at the disposition of the mentors to use and sometimes uncensored, one cannot rule out completely the possibilities that some of the students may achieve less than their peers in the same nursing placement. Reacting to this Darling (1986) pointed out four main types of mentors that may be detrimental to student achievement to include, the avoiders, the dumpers, the blockers and the destroyers/criticisers.

To minimise biasedness in learning opportunities, structural lessons may be introduced in nursing placements to 
Assessing the components of mentoring in nursing practice placements. A Mixed study approach.

compliment modelling which has been the most common form of mentoring. (Bailey-Mchale and Donna, 2013). There are also challenges met in defining mentor considering the various forms and context of mentoring. More than 50 definitions were found by Crips and Cruz (2009) when evaluating just the social science literature. According to Brondyk and Searby (2013), the definitions of a mentor may be describing the various phenomenon which may include, the process of mentoring, the people (Mentee and Mentors) and their behaviours. A more traditional definition of a mentor focuses on a relationship between an old and more experienced mentor and a younger and less experienced protégé with the intention of helping the mentee develops in the career, (Kram, 1985). This definition depicts a hierarchy in the relationship, the people, and purpose. This mentoring relationship is described by Blackwell (1989) as a "process in which a person with a superior rank, special achievement, and prestige instruct, counsel, guide and facilitate the intellectual and/or career development of persons identified as protégés". In this context mentoring can be seen as being directive, a situation in which the mentor is seen as one of a higher hierarchy holds the power to disseminate knowledge to the mentee who is at the receiving end to emulate (Brondyk and Searby 2013). Asada (2012) referred to it as a "stance of objectivism", in which the mentor/mentee dyads may give rise in having the mentor impose his or her views upon the protégé. This mentoring model can also be referred to as cloning in which the mentor seeks not only to direct but also controls the mentee (Buell, 2004).

Contrary to these traditional definitions, Zachary (2012) illustrates mentoring as a relationship of mutuality in which learning is reciprocal and collaborative directed by the mentor with clear and mutually learning goals. Relatively to the latter, a mentor according to Bennetts (1994) is that person who develops a one to one learning relationship with a mentee and is accountable to bring about personal growth to the learner at the end of the mentoring period. These definitions indicate a relationship of trust and mutual respect in which the mentor supports the mentee with the view of fostering the potential and achieving the learning objectives while considering the needs of the mentor and the context within which they both must function (Kochan, 2002). This implies that mentoring, "moves beyond emotional support and brief advice to become truly educative, focused on learning opportunities that move novices' practice forward and challenge their thinking and practice" (Achinstein and Athanases,2006).

In as much as there may be many benefits emanating from mentoring, Bean et al., (2014); Maxwell, (2013), some of its paradigms when poorly utilised may be seemingly controversial to the very ideals which nursing stands for. Eller et al. (2014) identified eight elements that can improve the mentee/mentor relationship to include the following: caring personal relationship, mutual respect and trust, exchange of knowledge, role modelling, goals and challenges, independence and collaboration, passion and inspiration, and open communication and accessibility.

Cultural diversity is another aspect that may seem to be problematic in a mentoring relationship. In a diverse society as in the UK, it is expected most organization should take the responsibility in setting out principles that may support those from culturally diverse backgrounds. In consideration of this, The National Health Service NHS, and the Equality and Diversity Council are emphasising the promotion of equality and examining inequalities as core values requiring constant review. (Shared Intelligence, 2012) This is seen in the development of the Equality Delivery System EDS "a tool designed to embed equality within the current and future NHS with the intention to support NHS organisations deliver better outcomes for their patients, carers, communities and staff'( Shared Intelligence, 2012). According to Blake-Beard et al.(2007), "the impact of race on mentoring relationships is an important question to raise, first and foremost because the changing composition of the workforce means that individuals will experience more cross- race (and cross-cultural) interactions within organisations of today and tomorrow". Nursing is one of those professions that embraces students from diverse cultures, race, gender, age, religion and sexual orientation. In nursing practice placements, there may be some probability that the mentees and mentors may not share the same values in terms of race and cultures. Regins (2007) also point out that diversity characterises most aspects of the life of an organisation and this may go beyond race to include, diversity in economic class, disability, gender, age, religion and sexual orientation.

In order to find answers to some of the above questions the researcher will assess some of the vital components of mentoring, and other emerging themes that underpins effective learning in clinical placements.

\subsection{The Problem of Study:}

The failure of a mentor in using an appropriate approach to mentoring that will structure and plan meaningful learning experience to suit individual needs may, undermines creating a favourable didactic relationship and learning environment. In a case where the mentor is presented as an avoider, the dumper, the blocker and the destroyer/criticiser (Darling et al 1986), there may be a higher tendency that the objectives of mentoring may be in jeopardy. Further to this Bailey-Mchale, and Donna (2013), opines "unplanned lesson is one which often fails to meet the needs of the students".

Cultural competence is another aspect which mentors may want to consider as a panacea in mending a 
didactic relationship with their mentees. In situations where mentors fail to recognise that cultural competency may enhance the quality of learning in a clinical environment, may lead to misunderstanding and conflict (Kent, Kochan, \& Green, 2013).

The mentee should be aware of his/her roles in a placement setting and would be beneficial if that is established between the mentor and the mentee at the very beginning of the placement. Seemingly that may motivate the student to be more proactive and confident in addressing issues with the mentor when the need arises. Considering Lipscomb (2010), the role of a mentor is more collaborative than didactic, thus it may be problematic where a mentee fails to take firm responsibilities in accomplishing his/her roles to maximise learning.

The role of a mentor involves supporting and assisting the mentee to comprehend the need for evidence-based practice since this will influence the three domains of mentorship: facilitating learning, assessment, and creating an environment for learning (Kinnell and Hughes, 2010). It is for this reasons that the Nursing and Midwifery Council NMC (2008) recommends that nurses must at all times deliver high standards of care and practice and in so doing make sure care is given in accordance with best practice and evidence. Conversely not instilling this culture on to the mentee may lead to the promotion of unsafe practices.

\subsection{Research Questions:}

Does the appropriate use of the components of mentoring brings about meaningful results in the Mentor/Mentee dyads?

Are structured ward base blueprints and lesson plans used to achieve student's objectives during placement?

Is cultural competency required to improve Mentor/Mentee relationship?

Are evidence base practices necessary to improve Mentor/Mentee relationship?

\subsection{The Purpose of study.}

This study will help both mentors/students to have more insight into their roles in the mentoring relationship. The study will also help mentors, encourage and guide students whenever they are failing in their roles.

The study will help students identify a mentor who is not meeting expectations and seek for support where possible.

The study will provide information as to the need of using evidence as a way of best practice.

This study will help both mentee and mentor to focus on the respect for cultural diversity whilst at work and as a vital instrument in the mentor/mentee dyads.

\section{Data Search, Inclusion/Exclusion criteria/Rational.}

\section{Methods}

A systematic literature review was conducted by the researcher from English-language text currently published. According to Parahoo (2006), a systematic review is "a rigorous search, selection, appraisal, synthesis and summary of the findings of primary research in order to answer a specific question". In considering the audit aspect of the review Bryman (2015) maintains it, " highlights the most relevant evidence of each case and sets into place a precise and functional review of the specific evidence, study procedures utilized and recommendation from conclusions, if not detailed gaps found." Bryman (2015), further states, "It is important to chart out what the exact parameters and search terms exist for the review as this will allow the case studies to systematically fall into place for specific categories."

To chart out specific parameters for study, the researcher explored a phenomenon approach. According to Mackey (2005), Researchers in the field of nursing have found that phenomenological approach allows for the ways of doing research which is consistent with nursing models and theoretical conceptualisations. Mackey (2005) in this study concluded that "Phenomenology's philosophical premises accept human experience as a valuable source of knowledge, and its methodological approaches allow, and indeed encourage, the complexity and depth of human experience to be expressed". This study will be exploring as a phenomenon, students' and mentoring experience whilst in placement as basic inclusive criteria. All findings, therefore, that relates to Mentee/Mentor Dyads and specifically mentoring styles, cultural diversities in the relationship, best practice, and the mentee's role whilst at placement will be included.

A qualitative design hence will be the main design of focus as it compliments phenomenological studies to the extent that it considers the human perspective in a natural environment, Parahoo (2006), and evaluates the motives and reasons for people's perspectives, beliefs, and behaviours, so as to find a better insight into people's lived experience (Donley, 2012).

Most of the literature used to review the study was drawn from accredited academic journals including International Journal of Nursing Studies, Science Direct, American Psychological Association, FYHE International Journal, and Nurse Education Today. These Data Base sources are peered reviewed; implying that the article had been read by authorities in the area of study and the accuracy and appropriateness of the 
methodology used in the study validated and considered to be trustworthy (Burns and Grove, 2007). Where necessary some textbooks addressing the research questions were used. The search words used include mentoring, mentoring and cultural competence, mentor/mentee dyads, the mentoring role of the mentee, and best practice in mentoring. This searches gave over a thousand results for each impute.

Through random sampling, the researcher quickly browses through the abstracts of articles and when relevant, further checked on the findings and then content before making a final decision to select which articles are needed at this stage. A simple random sampling according to Parahoo (2006) is best suitable for a more or less homogenous population and will minimise biases to a greater extent from each sample drawn. In the case of this study, except for the variable referring to structured ward base blueprints and lesson plans, the other phenomenon are homogeneous on the basis that they are all drawn from mentor/mentee dyads.

In the first round search two hundred articles representing each phenomenon were chosen and reserve in clusters. A simple random sampling was further conducted on each cluster to reduce the articles to a manageable size also taking into consideration which of the articles best address the research questions.

On the question on if students are introduced to a framework of a standard ward base skills at the beginning of placement and if there were lesson plans designed to achieve these skills, the interview was used to collect data. This was because the researcher being a nurse finds it faster and easier to collect data from colleagues and student nurses whilst in and out of work. These key informants will have unique access to information and unique perspectives on the research phenomenon (Gravetter and Forzano, 2006).

This was limited only to generate data to find out if there is a structured plan, designed by the ward common to all the mentee during placement. A face to face interview was carried out with 30 respondents mainly from students who are presently on placement and registered nurses with at least six months to one year experience. The registered nurse may or may not have experience in mentoring, as the study is more about sharing their experiences as a mentee and not as a mentor. A standard lesson plan (appendix 1) and a standard ward base framework (appendix 2) was shown to the respondents to ease comprehension of the phenomenon in question. Descriptive statistics was used in this category to analyse this research question, in which respondents were restricted to a yes or no response and according to Gravetter and Forzano, (2006), these limited and predetermined responses are faster and easy to analyse.

The percentage was used for analysis and as a descriptive statistics the researcher was interested to find out the presence or absence of certain phenomenon and not necessarily to prove a cause or effect or to make the inference (Gravetter and Forzano, 2006). For the same reasons the researcher did not use a large sample size and only thirty respondents were used to represent the sample group. Convenience sampling method was used for data collection from population members who are conveniently available to participate in the study (Parahoo, 2006). The target population, therefore, will be any nurse that may have any experience in mentoring dyads either whilst as a student or as a mentor, and the student nurses.

The Researcher will also use the currency of publications as inclusive criteria. Only recent articles published within the last five years are intended to be reviewed in relation to the selected phenomenon of the research. Most of the sources cited in the research report are of recent origin. Coughlan et al. (2007) state that studies should be less than five years old if they are to be considered current. The Researcher, however, may be reviewing some of the studies beyond five years in cases where such findings are similar to those of current studies (Parahoo, 2006).

\section{Results}

A total of 80 articles were selected following a preliminary search of data. These articles were read with more intensity also concentrating on the results and researcher finally selected 24 articles addressing the research questions. Four main themes emerged at this final screening to include components of mentoring, cultural competency, evidence base practice, and ward base framework or blueprints.

3. 1 Components of Mentoring: In reviewing the components of mentoring sub-themes emerged to include, open communication, goal setting, trust and respect, Knowledge, and friendship.

\section{1:1 Open Communication:}

In a study on the key components for effective mentor/mentee dyads, Eller et al (2014) came to a conclusion that, whereas the mentors are emphasising on their need to provide positive and negative feedback, students will focus on positive feedback. They maintained this difference is an indication of the mentee's vulnerability and their endless desire for a safe environment in which the mentors can listen without criticism. Mentors that are critical may bring about problematic outcomes (Ehrich et al. 2004). Haggard and Turban (2012) therefore maintained that the most important obligation of the mentor should be acceptance. Similarly, Huybrecht et al. (2011) also identified the provision of feedback to protégés as an important function of the mentor. Respondents in Eller et al. (2014), expressed their need for supportive feedback, mentors that are 
approachable and non-judgemental, and mentors that are honest and not hash. This implies that with effective communication with the mentors, students will be motivated to develop their potential and also gain confidence in their skills (Eller et al.2014). It is critical that mentors and mentees seek to understand their own and the other's communication styles, and take time to practice communication skills

\subsubsection{Goal Setting:}

Eller et al (2014) opine, the "time management, the setting of timelines as well as individualizing the work based on protégés' learning needs were all components of goal setting". Setting goals according to Bandura (1997) will increase the development of a sense of self-efficacy and the achievement of greater skill acquisition through resilience training. It is, therefore, eminent that when mentors assist students in mastering overwhelming challenges they will be contributing to student's growth (Eller et al., 2014)

\subsubsection{Trust and Respect:}

In a study carried out by Haggard and Turban (2012) trust and respect was identified by the mentors and protégés in their relationship as relational obligations. In Sherman (2005) trust and honesty were highlighted by nurses as the outstanding qualities to be acquired by a mentor. Ehrich et al., (2004) also asserted when mentors are "untrusting" the protégé outcomes will be open to uncertainty. Frels \& Onwuegbuzie, (2012); Wong, et al. (2013) found that mentor practices that emphasize relationship and trust building were found to be essential to the success of these dyads.

\subsubsection{Knowledge:}

Koskinen and Tossavainen,( 2003) maintain, the mutual or reciprocal learning, which is experienced as very rewarding is one of the most positive effects for mentors. Ehrich et al., (2004) and Lechuga, (2011) expressed a similar view on career/vocational functions of mentoring which included sharing ideas, knowledge, and skills and educating. In Eller et al. (2014) respondents emphasise the need for mentors to provide "real world" knowledge and focus on a bigger picture. Assisting a mentee in developing his/her potentials in both a personal and professional level is a major responsibility of a mentor (Lipscomb, 2010). "A mentor can help a mentee by guiding them in the right direction or giving them another perspective on an idea they had not thought of" (Lipscomb, 2010). Similarly, Huybrecht et al. (2011) opine, "Sharing of new knowledge and experience as well as close follow-up of new developments in the field compensate for the investment of time and effort".

\subsubsection{Friendship:}

In Haggard and Turban's study (2012) friendship is earmarked by protégé as a vital relational obligation for mentoring although mentors did not. A reciprocal relationship, however, was highlighted, by Zachary (2012) as being essential for successful mentoring. In Hauer et al. (2005) the medical students also highlighted friendship as a valuable component of mentoring. Friendship as a positive outcome for protégé in education studies was also reported by Ehrich et al. (2004) in a related study. In this study all the participants considered the mentoring relationship to be a friendship rather than just a professional relationship.

Buell, (2004) describes friendship model as that in which, "the mentor and mentee were viewed as peers rather than being involved in a hierarchical relationship, and collaborative, reciprocal, a mutual engagement was the norm". Shelmerdine and Louw (2008) in an attempt to establish how friendship could be beneficial in a mentoring dyads differentiate two types of friendship, that of help and that for its own sake. She said the relation of friendship for its own sake is reciprocal and mentee and mentor may share information about themselves and learn from each other. She added, mentors of this category are, "sensitive and responsive to their mentees' needs and circumstances, displaying an ability to empathise with them, and to listen, understand and affirm their mentees' own knowledge". On the contrary the friendship for help is detrimental as the mentor sees him or herself as the embodiment of knowledge. Shelmerdine and Louw (2008) thus maintained that "mentors in those relationships dominated by a narrative of help attempt to control both their relationships and their mentees, and to 'pass down' advice, models of behaviour, and so on, instead of affirming their mentees' own knowledge".

\subsection{Cultural Competence.}

It is important to understand the influence culture plays in terms of the benefits and difficulties experienced in a mentor/mentee relationship. Educating health professionals on cultural competence provides opportunities for them to pay attention in respecting and responding to a range of beliefs, the ways of being and values of the workers and service users (Walsh, 2010). According to Blake-Beard et al. (2011), mentees will prefer and indicate more satisfaction in a racially homogeneous mentor relationships. In Blake-Beard, et al. (2011) it was also revealed that minority students paired with European mentors will gain fewer benefits in the 
mentoring/mentee relationship and psychosocial support than protégé in the same race dyads. The implication here could be that where cultural competency is not taken into consideration there will be more difficulties in communication, lower satisfaction, and less ease in a mixed race mentoring dyads than in the same race dyads (Ortiz-Walters \& Gilson, 2005). In previous research, students have shown an awareness of this and strongly expressed their view on perceiving drawbacks in their possibilities of learning due to lack of language skills and their cultural backgrounds (Mikkonen et al., 2016). Meyer (2015) found out that the levels of relationship satisfaction and interpersonal comfort are dependent on shared value and effective communication. In an attempt to address the issues arising from demographic variables such as ethnicity, religion, class and gender, Meyer (2015) further reveals that in a diversified mentoring relationship, dyad members are more inclined to a number of challenges related to differences in communication style or work ethics than are demographic differences.

\subsection{Evidence-Based Practice.}

"Evidence-based practice requires a culture of inquiry, a culture in which professional nurses develop and practice critical thinking skills as well as clinical decision making, role model the questioning attitude and behaviours, and are continuously exposed to research and best evidence"( Fitzpatrick, 2007). The role of a mentor will be to support and assist health care students to understand the need for evidence-based practice as this will influence the three dominant themes of mentorship which are facilitating of learning, assessment, and creating an environment for learning (Kinnell and Hughes 2010). Mentors must, therefore, remember that "the end product of evidence-based practice is the ability to offer research-based findings in order to justify aspects of care delivery and rational for experiences encountered by patients throughout their health care journey in order to avoid bottlenecks and backlogs" (NHS, 2007). Taking this into consideration, "students are encouraged to gain an awareness and appreciation of underpinning theoretical perspectives that validate the professional reputation associated with nursing" (NMC, 2008).

\subsection{1: Availability of Ward base framework at the Start of placement:}

The researcher interviewed 30 participants to include nurses and student nurses. Table 1 shows that $100 \%$ of respondents testify to the fact that no ward base blue print for learning activity was presented to them during their placement.

\begin{tabular}{|l|l|}
\hline Percentage & Respondent N=30 \\
\hline $0 \%$ & Yes N=0 \\
\hline $100 \%$ & No N =30 \\
\hline
\end{tabular}

Table 1

3.4.2: Usage of lesson plan to achieve objective:

Table 2 indicates $100 \%$ of respondents confirm there were never exposed to any structured lessons in which lesson plans were used as guideline.

\begin{tabular}{|l|l|}
\hline Percentage & Respondent $\mathrm{N}=30$ \\
\hline $0 \%$ & Yes $\mathrm{N}=0$ \\
\hline $100 \%$ & No $\mathrm{N}=30$ \\
\hline
\end{tabular}

Table 2

\section{Discussion}

Mentoring plays a central role in directing how a trainee will provide health care service during training and after completion of course by imparting on their professional development and clinical experience (Ferrara,2012; Madhavanpraphakaran et al., 2014; McIntosh et al., 2014;). In Eller et al. (2014), sharing the experience of the mentee, they were in the opinion that "mentors should lead by example, model interactions with others and share struggles, historic and present, to reduce the intimidation factor." Mentors, therefore, provide role modelling for leadership and ethical behaviour. Platis (2014) maintained that a positive style of leadership initiated would make the nurses more focused, structured, and know in advance what is expected of them.

The finding of this study reveals that the key components of mentoring will have positive outcomes on the mentee. This corroborates with the findings by Demir et al. (2014) that when these elements are properly utilised by the mentor, students will develop positive attitudes towards the skills s/he is engaged with the mentor, self-awareness, problem-solving, and self- confidence. This concept allows opportunities for the mentor to listen and provide advice to the mentee in stressful moments and in providing counselling on personal and job-related issues. It also gives room for a mentor to challenge the protégé's negative self-views Rhodes (2005) as such bolstering self-confidence (Johnson 2007). The concept of the mentor working in collaboration with the 
Assessing the components of mentoring in nursing practice placements. A Mixed study approach.

key components of mentoring brings about trusting relationship with the mentor thereby motivating the protégé to transmit interpersonal relationship with others in clinical settings (Rhodes, Grossman, \& Rensch, 2000).

The mentor may be viewed as a custodian of knowledge and experience but still needs to comprehend the perception and the understanding of the mentee in order to succeed $(\mathrm{Ng}, 2012)$. In the relationship, the mentor is not just seen as a guide and listener but a partner (Kochan 2013)

In setting goals and imparting knowledge and expertise, the mentor will contribute to the protégé's learning and skill development (Mullen, 2007). However, for the fact that the mentor/mentee dyads are reciprocal the student role in the relationship has a vital effect upon the nature of the learning experience in the clinical setting (Mikkonnen et al. 2016). According to Miguel and Rogan, (2012), effective learning will be achieved when students take initiative and are responsible, self-directed, empathetic, enthusiastic, ongoing, and motivated. Lee et al. (2015) describe this as, "mentoring up, a concept that empowers mentees to be active participants in their mentoring relationships by shifting the emphasis from the mentors' responsibilities in the mentor-mentee relationship to equal emphasis on the mentees' contributions". This adaptive mentoring model according to Godden et al. (2014); Salm and Mulholland (2015) is not limited to complex mentoring roles, rather it emphasises the importance of the mentee's behaviour, attitude, and competencies. This concept, when transferred to mentees, may support them in the way they engage with patients later in their career in improving the quality of care. Newman et al. (2015) maintain that when the service users are involved in the care planning, making decisions in their care, will enhance positive self-identity, confidence, and social recovery. Pryce (2012) also highlights the "attunement in therapeutic relationship". This depicts a relationship that goes beyond empathy to incorporate a bond of interpersonal contact and facilitating psychological healing (Erskine, 1997). Protégé's initiative, however, may not be utilised effectively where the mentor fails to provide the leadership role in providing a blueprint in which students may make decisions or reflect on what to do. Teasdale (1993) argues that much clinical teaching is inclined to modelling and are unstructured. He thus proposed that mentors should structure their teaching, pointing out the fact that there is a difference in teaching nursing and practicing it, between transmitting expertise to others and displaying it. This setback may be corrected with the use of a teaching plan. Bailey-Mchale and Donna (2013) argue that "lesson planning is a cycle strongly reminiscent of the nursing process but often ignored and the unplanned lesson is the one which often fails to meet the needs of the students". These are in accordance with the finding of this study that $100 \%$ of the respondents agreed to the fact that, there were no lesson plans provided, neither were there any hospital ward base blueprints presented in their placements. It also justifies the reason "new graduates frequently express concern that, during their undergraduate clinical placement, the opportunity to learn and develop competence in preparation for their graduate role did not always occur" (Brammer, 2006). Hale's studies (2000) confirmed that mentees may find it less difficult to acquire knowledge, skills, and behaviours through formal mentoring programmes than in a traditional training setting.

In regards to approaches in contemporary nursing health care, McEwan (2006) pointed out the influence that is changing and continues to change. She declares that "largely due to the work of the nursing scientist, nursing theorist, and nursing scholars over the past four decades, nursing has been recognised as both emerging profession and an academic discipline". This development is reflected in the emphasis laid on evidence-based practice in the modern day nursing. The Mentor thus should recognise the fact that the uniqueness of evidence-based practice is to ensure that the care delivered to patients is researched based, and not a result of nursing rituals. According to Brown (2008) "effective nursing practice requires information, judgment, skills, and art" This Author further outlines the guidelines which mentors have to pursue in order to appreciate the importance of evidence-based practice. This include "recognise when nursing care being given is not as effective as it might be, locate research bases guideline and research summaries, be comfortable reading research articles, develop basic skills in judging if a clinical practice guidelines or research summary was soundly produced, decide if the evidence available is strong enough to use as a basis for nursing care, and participate in the development of protocols in the agency or unit in which you work".

Cultural competency is another vital aspect in mentoring dyads. "Culture plays a critical role in how individuals develop and function in a society; it guides and shapes their values, beliefs, and behaviour throughout their lives" (Fong et al. 2016). Cultural competency begins with understanding one's cultural identity at the most basic level and this awareness may predict the extent to which one's circumstances, preferences, characteristics, and values differ from those of others (Fong et al., 2017). This may be important in chosen a mentor that may be compatible and suits the needs of the protégé also providing a favourable environment for learning. However whilst others may base their priority on a friendly relationship, some may consider specific skills expected to learn from the mentor (Lipscomb, 2010).

It is important for student nurses to be nurtured in the environment where cultural competency is not just an option but regarded as a need "for serving an increasingly multicultural background of consumers" (Fong et al., 2016). Though cultural issues set a difficult precedent for mentoring dyads, Kent et al (2013) maintain that when mentees and mentors are committed the relationship will succeed. This type of commitment, however, 
could only be effective where trust is paramount in the mentor/protégé dyads.

In a study carried out by Leck and Orser (2013) on how trust fosters mentoring relationship "trust was largely influenced by the mentor's perception of four important dimensions: protégé ability, protégé benevolence, protégé integrity, and risk".

Protégé's ability was referred to a group of skills or behaviour the mentor expects the protégé to express in order to be trustworthy. Leck and Orser (2013) identify them as "demonstrating a willingness to learn, demonstrating openness, seeking out the mentor, listening to advice, the ability to set realistic goals, and being able to receive honest feedback".

Mayer et al. (1995) described benevolence as "the extent to which a trustee is believed to want to do good to the trustor" and suggested that it suggests a "specific attachment" to the trustor. Leck and Orser (2013) referred to benevolence as the feelings that may lead to trust and the investment in the mentoring relationship, such as the feeling of being safe, natural chemistry, connection, and a sense of love. The basic elements underpinning these principles were identified by Leck and Orser (2013) to include keeping a confidence and declaring a conflict of interest.

Leck and Orser (2013) also identified the time, major events, and gender as the three contextual elements that will influence perceived risk. Time well spent with protégé they explained will enhance trust in a mentoring relationship. Involving in a major event such as designing a personalised plan to be utilised by mentor and mentee will increase trust. The Same gender was also found to enhance trust in a mentor/protégé dyads.

\title{
V. Conclusion
}

In a systematic review of the relevant literature, the findings reveal some key components of mentoring that can enhance not only mentoring dyads but provide learning opportunities for the mentee to imbibe skills valuable in their future career. Mentors are expected therefore to support the mentees to develop skills that will promote independence. There is a focus on mentee roles that means a reciprocal impute where necessary in nursing placement, will be beneficial to both parties. The Researcher also addresses cultural competency in the context of mentoring as a core value to establish effective mentoring dyads but highlighting the fact that a proper relationship is retained based on a commitment from both the mentee and mentor. Formal mentoring and evidence-based practice also takes a commonplace, as there is a need for mentors to update their knowledge rather than clinch on practices based on nursing rituals.

It was a limitation that only small sample size and convenient sampling was use in the study, reducing the possibility to make an inference. However, the study was meant to identify the presence and absence of certain phenomenon and in some themes to describe the benefits of mentoring. This also evident in the fact that the researcher uses a systematic review and non-inferential data presentation for findings.

\section{Recommendation.}

The study recommends that further research should be carried out on the effect of formal mentoring on mentee performance. It suggests that mentors should not rely only on workbook or skills manuals developed by the universities but should be able to develop ward base blueprints to suit the learning objectives set by the universities. The study will help both students and mentors to use evidence as a baseline to practice and not just rely on past experience as knowledge continues to evolve in contemporary nursing. The study recommends that cultural factors should be considered as vital in the context of mentoring Dyads.

A much larger population across England should be used to represent the sampling size in future studies. Future study should be on the effects or relation of the key components of mentoring on learning outcomes. To find the extent to which structured learning as compared to modelling will influence mentoring could be an area of interest.

\author{
Appendix 1: Teaching Plan \\ seen below. \\ Subject: "Monitoring Respirations". \\ Aims: "Students will be able to accurately monitor respirations". \\ "Students will be able to accurately record respiration". \\ Objectives: \\ "Explain Normal Respiration". \\ "Explain Common respirations and the reasons for such". \\ "List the steps and techniques in the procedure". \\ "Measure and record respirations".
}

Bailey-Mchale (2013) presented a simple teaching plan that can be used for a structured lesson in placements as 
Assessing the components of mentoring in nursing practice placements. A Mixed study approach.

Content:

"Explain the normal biology and reasons for and types of variation".

"Explanation of procedure and correct ways of recording results".

Method:

Lecture

Demonstration

Practise

Appendix 2, Ward Base Practice Framework (Gateshead Health NHS Foundation Trust 2010)

The Clinical Placement as a Learning Zone.

Translating the practice environment from a broad range of experiences into a profile of learning opportunities.

\section{Welcome to Ward 3 Orientation Programme. \\ Ward Information.}

This pack has been designed specifically for Student Nurses who have been allocated a placement on ward 3, a medical ward which specialises in managing the acute stroke patient.At the start of your placement with us you will be allocated a Mentor, a qualified Nurse, who will facilitate you in meeting your learning objectives for this placement.In addition to this there will be opportunities for students to fulfil other learning objectives, which are not part of their summative assessment, but ones that are of personal interest, these will need to be negotiated with, \& arranged by your mentor.

\section{Contact; Education facilitator Ward 3 - 01914452003}

The education facilitator can be contacted prior to the start of the placement, to give you details of your Mentor and to discuss a start date and shift patterns. A pre-placement visit is not mandatory, but if you would like to visit the ward before your placement and meet your Mentor and other members of staff. This can be arranged through the education facilitator or by phoning the ward direct.

\section{We Hope That You Will Enjoy Your Placement.}

\section{Useful Information}

Shift Pattern:

The shift times may vary, but here are the most common at time of revision

$$
\begin{array}{lr}
\text { Early } & 07.45-15.15 \\
\text { Late } & 12.45-20-15 \\
\text { Full Day } & \mathbf{0 7 . 4 5}-\mathbf{2 0 . 1 5} \\
\text { Night Duty } & \mathbf{2 0 . 0 0}-\mathbf{0 8 0 0}
\end{array}
$$

\section{Off Duty}

Please refer to the ward off duty file that is kept in the filing cabinet behind the Nurse's station. Discuss off duty with your mentor. This should then be documented in the off duty file.

\section{Uniform}

Please wear student issue uniform. It is not advisable for you to bring valuables to work. There are locked male and female changing areas. The codes will be given to you on your first day and you will be assigned a locker. You may need to provide a small padlock. Jewellery must not be worn in this department in accordance with hospital uniform policy.

\section{Smoking}

Gateshead NHS Foundation Trust operates a no smoking policy on all its premises

Fire

At the beginning of your placement on ward 3 please familiarise yourself with the layout of the department and the position of the fire exits and extinguishers, also your local fire policy. Your Mentor will facilitate this. You should aim to complete this on your first shift. 
Assessing the components of mentoring in nursing practice placements. A Mixed study approach.

In the event of a fire, do not hesitate, break call point glass and dial 333 .

On hearing fire alarms stay with your mentor and await instructions from the Senior Nurse on duty. The Senior Nurse will decide whether to fully evacuate or compartmentalise the department.

\section{WARD 3 PROFILE}

Ward 3 comprises of 23 beds. 4 beds are designated as acute stroke beds and are used to facilitate immediate admission for acute stroke patients. We also admit general medical patients.

\section{NURSING STAFF}

1 Ward Manager,

2 Stroke Assessment Nurses (SAN) - currently job shared by 2 band 6 sisters 3 Junior Sisters - 2 are currently job shared by 2 SAN Nurses

Band 5 Nurses

Band 2 Health Care Assistants

\section{MEDICAL STAFF}

2 Consultants

2 Specialist registrars

1 F2 Senior House Officer 1 F1 House

Officer

\section{OTHER STAFF}

2 House keepers Physiotherapists Physio Team Assistant Occupational Therapist Domestic Staff Pharmacist Pharmacy technician. Specialist Nurses.

\section{NON WARD BASED RESOURCES}

Business Manager Modern Matron

\section{Admissions and transfers to ward 3.}

Although ward 3 speciality is acute stroke we have other general medical patients transferred from MAU. Stroke patients are admitted from a variety of sauces. Direct admissions from G.P. or A/E. Transferred from MAU, or any ward in the Q.E. We also take many transfers from other hospitals.

When patients are transferred to ward 3, a full secondary assessment is carried out, including risk assessments, ADLs and social assessments in anticipation of discharge planning.

In addition, all stroke patients are assessed for their suitability for continuous monitoring. Observations are recorded, including snobs, as well as a swallow assessment. A multidisciplinary approach is taken when planning care to ensure effective delivery of care is achieved. An effective communication channel is in place to ensure when planning care Nurses are able to refer patients quickly to the appropriate department, or individual team member, to assist or advice in all aspects of the patient's care. All stroke patients have multidisciplinary team notes, enabling all professionals involved to communicate effectively. These files are kept on the patient's bed, and will go with them to the rehabilitation ward, ward 22 Jubilee wing.

Multidisciplinary team meeting.

This is held every Wednesday afternoon, to discuss the stroke patients, set goals and objectives. As many members of the multidisciplinary team attend as possible, including nursing and medical staff. The multidisciplinary team consists of;

SAS Nurse. Physiotherapy team.

Speech therapist, and specialist Nurse. Dietician and specialist Nurse.

Occupational therapist. Community stroke team. Social workers.

Discharge liaison Nurse. Pharmacy team.

There is also a wide range of specialists teams we need to refer patients to at varies times such as; the Crop team, Diabetic Nurse Specialist, Vascular Nurse, Tissue Viability Nurse, Infection Control Team, Macmillan Nurses, Respiratory Nurses, Continence Adviser, Chaplains, Drug and Alcohol Team and the ECG department.

Information about the roles of the individual team members and specialist Nurses are available on the ward. Also available on the ward are the procedures to follow to contact the specialist Nurses 
KEY ELEMENTS ON WARD 3.

Anatomy, Physiology and Pathology.

Clinical Nursing Skills.

Communication Skills.

Health Education and Promotion. Management and Managerial Issues. Management of Patient Care.

Staff development. Quality Issues.

\section{Anatomy, Physiology And Pathology.}

\begin{tabular}{|c|c|}
\hline Relevant Resource. & Learning Opportunity. \\
\hline $\begin{array}{l}\text { Mentor, Nursing Staff, Medical Staff, Education and resource } \\
\text { files, Library, books, posters \& x-rays. }\end{array}$ & Normal anatomy, physiologyand pathology. \\
\hline $\begin{array}{l}\text { Mentor, Nursing Staff, Medical Staff, Education and resource } \\
\text { files, Library, books, posters, x-rays, coronary care staff, ECG } \\
\text { technicians, Cardiac Rehab Nurses, In-house training days. }\end{array}$ & $\begin{array}{l}\text { CARDIOVASCULAR SYSTEM } \\
\text { Angina. } \\
\text { Myocardial infarction. Heart } \\
\text { failure, LVF. ECG. } \\
\text { Medication. }\end{array}$ \\
\hline $\begin{array}{l}\text { Mentor, Nursing Staff, Medical Staff, Books, Library, } \\
\text { Education resource files. }\end{array}$ & $\begin{array}{l}\text { ELECTROLYTE BALANCE. } \\
\text { Normal fluid balance. } \\
\text { Dehydration. } \\
\text { Recording and understanding fluid balance charts. } \\
\text { Fluid retention, / Oedema. } \\
\text { Acidosis. } \\
\text { Reading and understanding blood results }\end{array}$ \\
\hline $\begin{array}{l}\text { Mentor, Nursing Staff, Medical Staff, Education and resource } \\
\text { files, Books, Diabetic Nurse Specialist, Dietician and } \\
\text { Pharmacy. } \\
\text { In house training days. }\end{array}$ & 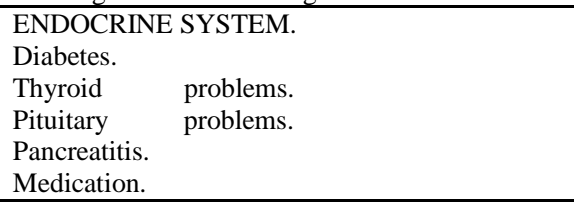 \\
\hline
\end{tabular}

Mentor, Nursing Staff, Medical Staff, Education and resource files, Books. Nutritional Nurse Specialist, Endoscopy staff. Dysphagia Nurse specialist, Macmillan and cancer specialist Nurses, Dietician, In house training days, Care Standards.

GASTROINTESTINAL SYSTEM.

Nausea and vomiting.

Diarrhoea.

Constipation.

Haematemesis / Maleana

Dysphagia.

Ulceration and cancers - upper and lower GI tract.

MANAGEMENT OF:

Nasogastric feeding. Peg

feeding.

Preparation for GI investigations. Post

procedure care. Bowel preparation.

HAEMATOLOGY.

Mentor, Nursing Staff, Medical Staff Education \& Resource files, Books, Library, Blood transfusion literature, Nurse specialist, Hospital and Infection control policies. Hematology and phlebotomy staff, In House Training days.

Blood formation and bone marrow function.

Red cells.

White cells

Platelets.

Collecting blood specimens. Blood

transfusion.

Haemorrhage.

Thrombosis

INFECTION CAUSES.

Mentor, Nursing Staff, Medical Staff Infection Control Team Infection Control Policies, Hospital policies, Library, Books,

Posters

Spread.

Infection screening.

Specimen collection

Prevention.

Barrier nursing. Reverse barrier nursing.

\begin{tabular}{|c|c|}
\hline $\begin{array}{l}\text { Mentor Nursing Staff and Medical Staff. Books } \\
\text { education resource files. } \\
\text { Nurse specialist. }\end{array}$ & $\begin{array}{l}\text { Liver and Biliary system. } \\
\text { Jaundice. } \\
\text { Tumours. Clotting } \\
\text { disorder. Liver failure. } \\
\text { Alcohol liver disease. } \\
\text { Cirrhosis. } \\
\text { ERCP. } \\
\text { Ascitis. }\end{array}$ \\
\hline
\end{tabular}


Assessing the components of mentoring in nursing practice placements. A Mixed study approach.

\begin{tabular}{|l|l|}
\hline & Musculoskeletal System. \\
Mentor, Nursing Staff, Education and resource files, Library, & Subluxation shoulder \\
Books Physiotherapy team, Medical Staff, Occupational & Muscle tone- tightening / loss. Botox. \\
Therapy Team, Community Stroke Rehabilitation Team, & Drop foot. \\
& Posture. \\
Contractures of limbs and fingers. Sitting \\
positions, \\
\hline \\
Nervous System. \\
Brain tumours. \\
C.V.A. (stroke) \\
Tentor, Nursing Staff, SAN Nurse, & T.I.A. (mini stroke) \\
Etroke team, Medical Staff. Library, Books, Educational and & Multiple sclerosis \\
resource files. & Guillain- Barre Syndrome. Myasthenia \\
The various Nurse specialists. & Gravis Headaches, migraines, cluster \\
& Infections. \\
& C.T. scans. \\
M.R.I. scans. \\
\hline
\end{tabular}

\begin{tabular}{|c|c|}
\hline Relevant Resource. & Learning Opportunity. \\
\hline $\begin{array}{l}\text { Mentor, Nursing Staff, Medical Staff, Infection } \\
\text { Control team, Specialist Nurse, Library, Books and } \\
\text { Education resource files }\end{array}$ & $\begin{array}{l}\text { Renal and urinary system. } \\
\text { Acute/chronic renal failure. } \\
\text { Urinary tract infections. Urine } \\
\text { testing. } \\
\text { Specimen collection. Catheter insertion } \\
\text { / removal. Fluid balance. }\end{array}$ \\
\hline $\begin{array}{l}\text { Mentor, Nursing Staff, Medical Staff, } \\
\text { Respiratory Nurse Specialist team, Library, Books, } \\
\text { Education resource files, Pharmacy team, } \\
\text { Lung Cancer Nurse Specialist. }\end{array}$ & $\begin{array}{l}\text { Respiratory System. } \\
\text { Chest infections. } \\
\text { Aspiration. } \\
\text { C.O.P.D. } \\
\text { Asthma. } \\
\text { Drugs, inhalers, nebulisers. Oxygen } \\
\text { therapy. } \\
\text { Tumours / lung cancer. }\end{array}$ \\
\hline $\begin{array}{l}\text { Mentor, Nursing Staff, Medical Staff. Books, } \\
\text { Education resource files. } \\
\text { Nurse specialist, Physiotherapist }\end{array}$ & $\begin{array}{l}\text { Skeletal System. } \\
\text { Rheumatoid , Osteo arthritis. } \\
\text { Infections. } \\
\text { Osteoporosis. }\end{array}$ \\
\hline
\end{tabular}

\section{COMMUNICATION SKILLS.}

\begin{tabular}{|c|c|}
\hline Relevant Resource. & Learning Opportunity. \\
\hline Mentor, Nursing Staff, Medical Staff, Ward clerk. & $\begin{array}{l}\text { Medical Staff ward rounds. Patient / relative } \\
\text { enquiries. Patient transfers within the trust. . } \\
\text { Verbal communication. }\end{array}$ \\
\hline Switch board. & $\begin{array}{l}\text { Using the telephone. } \\
\text { Receiving / giving information. Bleep system. } \\
\text { Nurse handovers }\end{array}$ \\
\hline $\begin{array}{l}\text { Mentor, Nursing Staff, Ward clerk. } \\
\text { M.D.T. staff. } \\
\text { Discharge Liaison Nurse. Community Based Services. }\end{array}$ & $\begin{array}{l}\text { None verbal communication. White boards. } \\
\text { Referral forms. Multidisciplinary team } \\
\text { notes. Ward diary. } \\
\text { Discharge medication sheets. Discharge } \\
\text { letter for D/N or Nursing home. } \\
\text { Patient transfers to other trusts. }\end{array}$ \\
\hline $\begin{array}{l}\text { Mentor, Nursing Staff, Ward Clerk. IT } \\
\text { department. } \\
\text { Policy / procedure file. }\end{array}$ & $\begin{array}{l}\text { Computer Skills. Understanding } \\
\text { confidentiality. } \\
\text { Access nursing documentation. Access patient } \\
\text { information. } \\
\text { Access patient's results. } \\
\text { Use the trust internet / E-mail. Ordering } \\
\text { equipment i.e. beds. Booking ambulances. }\end{array}$ \\
\hline
\end{tabular}

\section{CLINICAL NURSING SKILLS.}

\begin{tabular}{|l|l|}
\hline Relevant resource. & Learning Opportunity. \\
\hline & Administration Of Medication. \\
Mentor, Nursing Staff, Medical Staff, Pharmacy drug charts. Oral \\
Education Lesource file, Leaflets, books, & medication. \\
Library. & Nasal gastric / peg medication. \\
& Intravenous medication. \\
& Subcutaneous medication. \\
& Intramuscular medication Rectal \\
& medication. Infusions. \\
\hline
\end{tabular}


Assessing the components of mentoring in nursing practice placements. A Mixed study approach.

\begin{tabular}{|l|l|}
\hline & $\begin{array}{l}\text { Controlled drugs. } \\
\text { Restricted Drugs }\end{array}$ \\
& \\
\hline & $\begin{array}{l}\text { Aseptic technique. } \\
\text { Dressings. management. } \\
\text { Wound } \\
\text { Catheterisation. }\end{array}$ \\
Mentor, Nursing Staff, Medical Staff, Tissue viability & \\
Nurse, Infection control team, Books, Library. & \\
\hline
\end{tabular}

\begin{tabular}{|c|c|}
\hline $\begin{array}{l}\text { Mentor, Nursing Staff, Medical Staff, } \\
\text { O.D. training department, } \\
\text { file, Care standards, Hospital Policies. }\end{array}$ & $\begin{array}{l}\text { Cannulation } \\
\text { Site IV / S/C venflon. } \\
\text { Care of IV/S/C venflon. Obtaining blood } \\
\text { specimens. Phlebitis prevention }\end{array}$ \\
\hline $\begin{array}{l}\text { Mentor, Nursing Staff, SAN Nurse, } \\
\text { O.D. training department. } \\
\text { E.C.G. department, } \\
\text { Resuscitation officer, Policy } \\
\text { files. }\end{array}$ & $\begin{array}{l}\text { Clinical Devices. Using and } \\
\text { checking; Infusion pumps. } \\
\text { Syringe drivers. } \\
\text { Monitors } \\
\text { E.C.G machine. } \\
\text { Crash trolley / defibrillator. } \\
\text { B.M. machine. } \\
\text { Urine testing machine. }\end{array}$ \\
\hline RELEVANT RESOURCE & LEARNING OPORTUNITY \\
\hline $\begin{array}{l}\text { Mentor, Nursing Staff, Physiotherapy Team, } \\
\text { ergonomics department. } \\
\text { Risk assessment and policy file. } \\
\text { Education resource file }\end{array}$ & $\begin{array}{l}\text { Moving and handling. } \\
\text { Risk assessing patients } \\
\text { Use of equipment : Hoist. } \\
\text { Slings. Glide sheets. } \\
\text { Sam hall turner. } \\
\text { Banana board Pat slide. }\end{array}$ \\
\hline
\end{tabular}

\begin{tabular}{|c|c|}
\hline $\begin{array}{l}\text { Mentor, Nursing Staff, stroke team. } \\
\text { S.A.S. Nurse, respiratory team. Education } \\
\text { resource files. }\end{array}$ & $\begin{array}{l}\text { Physiological observations. Blood } \\
\text { pressure. } \\
\text { Temperature, pulse, respiration. } \\
\text { Oxygen saturation's. } \\
\text { Blood glucose. } \\
\text { Urinalysis. } \\
\text { Urine volumes. } \\
\text { Weight. } \\
\text { Maintaining accurate charts. } \\
\text { SNOBS ( Stroke Neurological Signs) }\end{array}$ \\
\hline $\begin{array}{l}\text { Mentor, Nursing Staff Medical Staff. } \\
\text { Endoscopy, ultrasound and sonar departments. Books, literature, } \\
\text { Leaflets procedure and policy files. }\end{array}$ & $\begin{array}{l}\text { Preparation for investigations. } \\
\text { Obtaining consent Information For each } \\
\text { investigation. } \\
\text { Administering the preparation. } \\
\text { C.T. scans of head. } \\
\text { C.T. scans chest / abdomen. } \\
\text { Ultrasound scans. } \\
\text { M.R.I. scans. } \\
\text { Endoscopy. Barium } \\
\text { studies. } \\
\text { Sigmoidoscopy. } \\
\text { Colonoscopy }\end{array}$ \\
\hline Relevant Resource. & Learning Opportunity. \\
\hline $\begin{array}{l}\text { Mentor, Nursing Staff. Policy files. Dietician } \\
\text { tissue viability Nurse. } \\
\text { Falls clinic. }\end{array}$ & $\begin{array}{l}\text { Risk assessment of a patient and The } \\
\text { appropriate action. } \\
\text { Falls. } \\
\text { Mouth care. } \\
\text { Nutrition. } \\
\text { Risk of pressure damage. } \\
\text { Documentation. }\end{array}$ \\
\hline
\end{tabular}

Mentor, Nursing Staff, Medical Staff. Procedure file.

Nurse specialists.

Education resource file.

Setting up equipment.

Catheter insertion.

Lumbar puncture.

C.V.P. line insertion / removal. Wound

dressing.

Fine bore feeding tube insertion. 
Mentor, Nursing Staff, Policy file Tissue viability Nurse.

Physiotherapy team, Occupational Therapy team.

Ergonomics Department
Using specialist beds and chairs. Assessing patient for bed.

Ordering beds.

Types of beds and how to use them. Assessing

patient for type of chair. Chairs available such as, Upright Parker

knoll Suffolk

HEALTH EDUCATION AND PROMOTION.

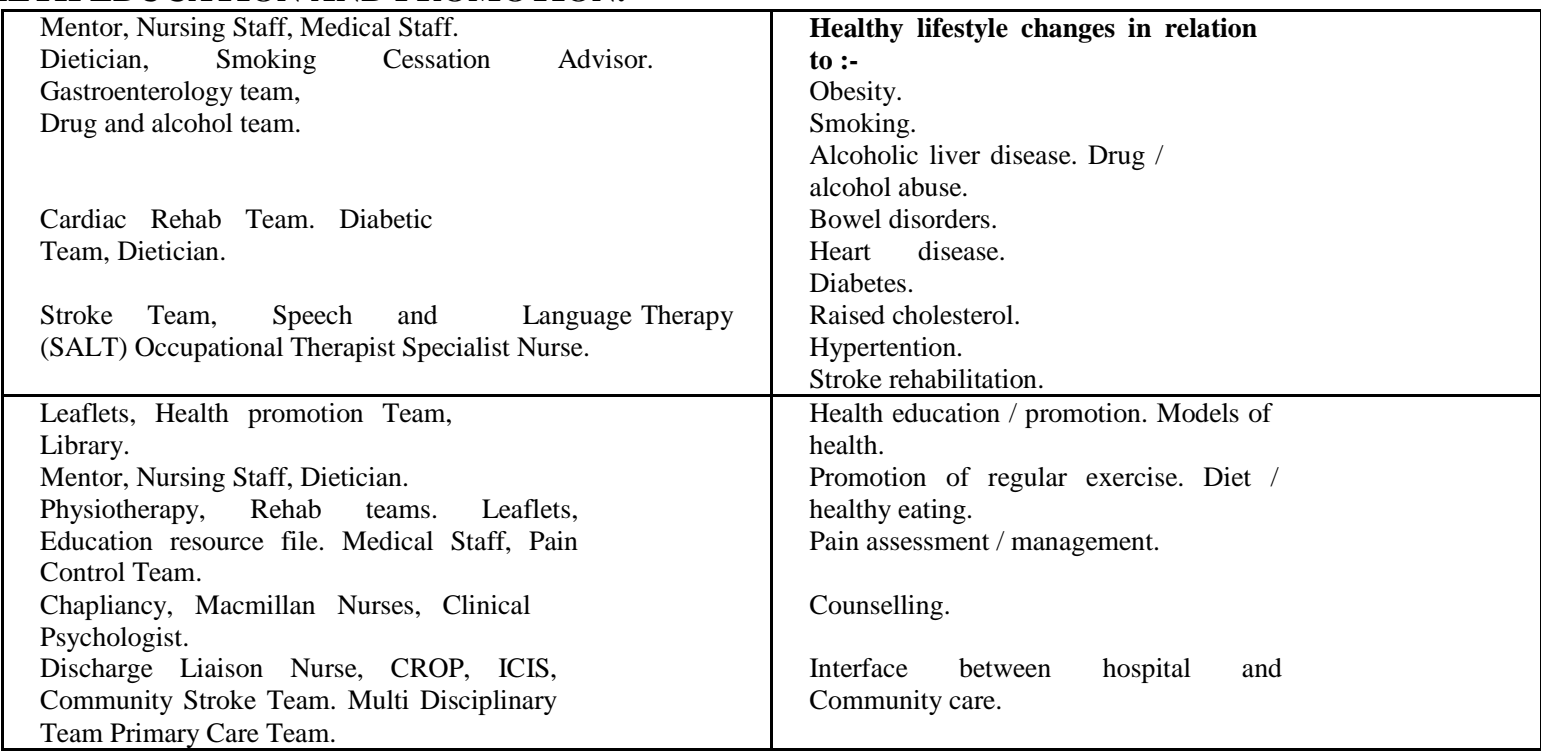

\section{MANAGEMENT OF PATIENT CARE.}

\begin{tabular}{|c|c|}
\hline Relevant Resource. & Learning Opportunities. \\
\hline $\begin{array}{l}\text { Mentor, Nursing Staff. Essence of care } \\
\text { files \& groups } \\
\text { Policy / procedure files, Intranet Care plans/ } \\
\text { pathways. }\end{array}$ & $\begin{array}{l}\text { Use of :- Nursing } \\
\text { model. } \\
\text { Essence of care. Documentation used. } \\
\text { Standards / protocols/ policies. Named } \\
\text { Nurse. }\end{array}$ \\
\hline $\begin{array}{l}\text { Mentor, nursing staff, SAN Nurse. Policies / } \\
\text { procedure files. } \\
\text { Patients / carers, medical notes. Education } \\
\text { resource file. }\end{array}$ & $\begin{array}{l}\text { Assessment. What is } \\
\text { assessed? } \\
\text { Who is assessed? } \\
\text { How is assessment carried out? When is } \\
\text { assessment carried out? }\end{array}$ \\
\hline $\begin{array}{l}\text { Mentor, qualified Nurses stroke Team SA n } \\
\text { Nurse. } \\
\text { Research literature. }\end{array}$ & $\begin{array}{l}\text { Planning. } \\
\text { Risk assessment tools. Care } \\
\text { plans. } \\
\text { Care pathways, i.e. stroke, or the Dying } \\
\text { patient. }\end{array}$ \\
\hline $\begin{array}{l}\text { MDT team members, individual Specialist } \\
\text { Nurses and Community Services. } \\
\text { Discharge Liaison Nurse. }\end{array}$ & $\begin{array}{l}\text { MDT involvement, i.e. physio, OT Specialists } \\
\text { Nurses community Based services. } \\
\text { Discharge planning. }\end{array}$ \\
\hline $\begin{array}{l}\text { Mentor, qualified Nurses, Medical Staff } \\
\text { MDT team members. Patient and } \\
\text { Relatives. }\end{array}$ & $\begin{array}{l}\text { Implementing / evaluation and } \\
\text { Documentation. } \\
\text { Ward rounds. } \\
\text { MDT meetings. } \\
\text { Care plans / document evaluate } \\
\text { Document interventions. }\end{array}$ \\
\hline
\end{tabular}

\begin{tabular}{l|l}
$\begin{array}{l}\text { Mentor, Nursing Staff, assessment Tools. } \\
\begin{array}{l}\text { Education resource files. } \\
\text { Tissue viability Nurse. Research. }\end{array}\end{array}$ & $\begin{array}{l}\text { Mouth care. } \\
\text { Skin care. Pressure area } \\
\text { care. }\end{array}$ \\
$\begin{array}{l}\text { Continence adviser. OT, } \\
\text { Continence. Washing / } \\
\text { dressing. Bathing. }\end{array}$
\end{tabular}

physiotherapy. 
Assessing the components of mentoring in nursing practice placements. A Mixed study approach.

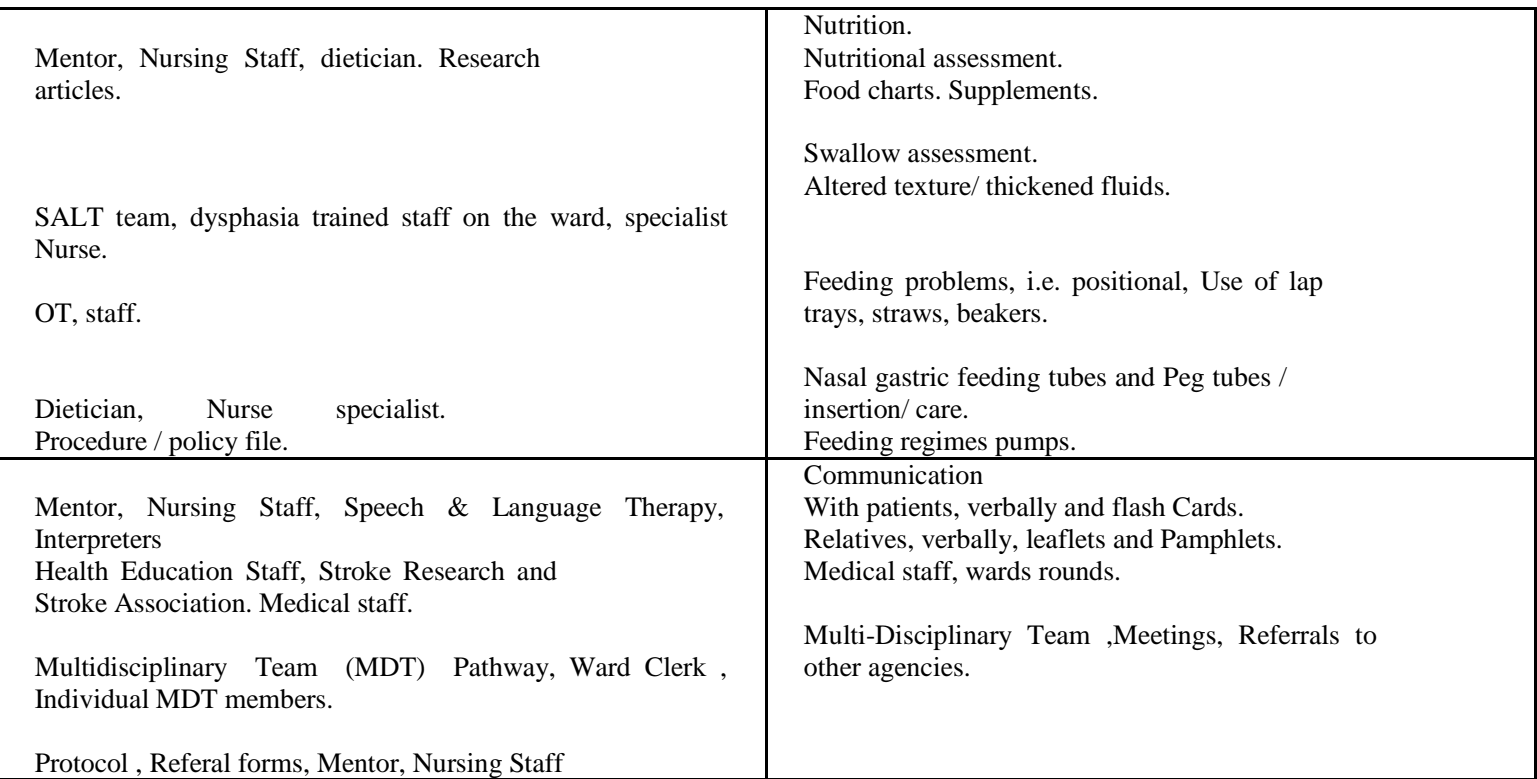

\begin{tabular}{|c|c|}
\hline $\begin{array}{l}\text { Mentor, qualified staff, policy file. } \\
\text { Modern matron. } \\
\text { Security/ hospital policeman. } \\
\text { Chaplains. }\end{array}$ & $\begin{array}{l}\text { Difficult situations : Self } \\
\text { discharge. } \\
\begin{array}{l}\text { Missing patient. } \\
\text { Patient/staff/visitors } \\
\text { property. }\end{array} \\
\begin{array}{l}\text { Deceased patients. } \\
\text { incident/accident. Missing }\end{array}\end{array}$ \\
\hline $\begin{array}{l}\text { Dietician catering staff. Mentor } \\
\text { Nursing Staff. Switch board. } \\
\text { Religious and cultural file. Housekeeper } \\
\text { Hospital chaplain service. }\end{array}$ & $\begin{array}{l}\text { Religious needs. } \\
\text { Special diets. } \\
\text { Access to patients own particular Religious } \\
\text { representative. } \\
\text { Time and place to prayer. } \\
\text { Communion. }\end{array}$ \\
\hline $\begin{array}{l}\text { Mentor,Nursing Staff. } \\
\text { Policy file, pharmacy staff. }\end{array}$ & $\begin{array}{ll}\text { Drug administration } & \text { policy. } \\
\text { Controlled drugs. } & \\
\text { Oral drugs. Intravenous } & \\
\text { drugs. Subcutaneous drugs } & \\
\end{array}$ \\
\hline $\begin{array}{l}\text { Mentor, Nursing Staff, Medical Staff, } \\
\text { Research articles. }\end{array}$ & $\begin{array}{l}\text { Anti embolic stocking. When / } \\
\text { why to use. } \\
\text { How to measure correctly. How to } \\
\text { apply. }\end{array}$ \\
\hline $\begin{array}{l}\text { Mentor, qualified staff. } \\
\text { Modern matron./ Ward Manager } \\
\text { Development programmes. } \\
\text { OD training department. Blue } \\
\text { File } \\
\text { KSF } \\
\text { Eduacation Staff } \\
\text { Individual }\end{array}$ & $\begin{array}{l}\text { Staff development: } \\
\text { Clinical supervision. } \\
\text { Reflective practice. } \\
\text { Contacts. development plans. Staff } \\
\text { Personal de } \\
\text { development prospectus. UNN. }\end{array}$ \\
\hline
\end{tabular}

\section{STAFF DEVELOPMENT. QUALITY ISSUES.}

\begin{tabular}{|l|l|}
\hline Relevant Resource. & Learning Opportunities. \\
\hline Mentor, Ward Manager, Nursing Staff. & Quality issues. \\
Modern matron / Medical & Policies. \\
Directive Team. & Procedures. Standards of \\
Research articles, Library Internet, Trust Intranet & practice. Research. \\
Research / audit departments. Practice & Clinical audits. Changing \\
Development Nurses. & practice. Handling \\
& complaints. \\
& Clinical incident reporting (Datix) \\
\hline
\end{tabular}

\section{References}

[1] Achinstein, B. and Athanases, S. (Eds) (2006), Mentors in the Making: Developing New Leaders for New Teachers College Press, Columbia University, New York, NY.

[2] Bailey- Mchale, H., and Donna, H. (2013) Mastering Mentorship. A Practical Guide for Mentors of Nursing Health and Social Care Students. London: Sage Publications. 
Assessing the components of mentoring in nursing practice placements. A Mixed study approach.

[3] Bandura, A., (1997) Self-efficacy: The Exercise of Control. Freeman, New York.

[4] Bean, N. M., Lucas, L., and Hyers, L.L. (2014), "Mentoring in Higher Education should be the norm to assure success: lessons learned from the faculty mentoring program, West Chester University, 2008-2011", Mentoring \& Tutoring: Partnership in Learning, vol. 22, (1), 56-73, DOI: 10.1080/13611267.2014.882606

[5] Bennetts, C., (1994) 'Mentors. Mirrors and Reflective Practitioners: An Inquiry into Informal Mentor/Learner Relationships', M.Ed. dissertation, Division of Adult Continuing Education Library, University of Sheffield.

[6] Blackwell, J.E. (1989) "mentoring: an action strategy for increasing minority faculty", Academe, Vol 75 No 5, pp 8-14.

[7] Blake-Beard, S., Bayne, M. L., Crosby, F. J., \& Muller, C. B. (2011). Matching by race and gender in mentoring relationships: Keeping our eyes on the prize. Journal of Social Issues, 67, 622-643

[8] Blake-Beard, S.D., Murrell, A. and Thomas, D. 2007. "Unfinished business: The impact of race on understanding mentoring relationships". In The handbook of mentoring at work: Theory, research, and practice, Edited by: Ragins, B.R. and Kram, K.E. 223-247. Thousand Oaks, CA: Sage.

[9] Brammer, J. (2006) A phenomenographic study of registered nurses' understanding of their role in student learning - An Australian perspective. International Journal of Nursing Studies 43. 963-973

[10] Brondyk S., and Searby L.J. (2013) Best practices in mentoring: complexities and possibilities. International Journal of couching and mentoring. Vol 2:3. PP 189-203

[11] Brown, S.J. (2008) Evidenced Based Nursing: The Research Practice Connection. Jones and Barlett Publishers.

[12] Buell, C. (2004) Models of mentoring in communication, Communication Education, 53:1.

[13] Chan, A.W., Yeh, C.J., and Krumboltz, J.D. (2015) Mentoring Ethnic Minority Counseling and Clinical Psychology Students: A Multicultural, Ecological, and Relational Model. Journal of Counseling Psychology. Vol. 62, No. 4, 592-607.

[14] Crips, G. and Cruz, I. (2009) "Mentoring college students: a review of the literature between 1990 and 2007”, Research in Higher Education, Vol.50, pp.525.545.

[15] Darling, L. A.W., (1986) What to do about Toxic Mentors. Nurse Educator. 11(2):29-30.

[16] Demir, S., Demir,S.G., Bulut, H., Hisar, F. (2014) Effect of Mentoring Program on Ways of Coping with Stress and Locus of Control for Nursing Students. Asian Nursing Research. 8, 254-260.

[17] Donley, A.M. (2012) Student handbook to sociology. Research methods. New York: Infobase Publisher.

[18] Ehrich, L.C., Hansford, B., Tennent, L., (2004). Formal mentoring programs in education and other professions: a review of the literature. Educational Administration Quarterly 40 (4), 518-540

[19] Eller, L., Lev, E., \& Feurer, A. (2014) Key components of an effective mentoring relationship: A qualitative study. Nurse education Today, 34, 815-820

[20] Erskine, R.J (1997) Trauma, dissociation and a reparative relationship. Australian Gestalt Journal. 1, 38- 47.

[21] Ferrara, L.R.F., (2012). Strategies for success as a clinical preceptor. Nurse Pract. 37 (5),49-53

[22] Fong, E. H., Ficklin, S., \& Lee, H. Y. (2017). Increasing Cultural Understanding and Diversity in Applied Behavior Analysis. Behavior Analysis: Research and Practice. Advance online publication. http://dx.doi.org/10.1037/bar0000076

[23] Fong, E. H., Catagnus, R. M., Brodhead, M. T., Quigley, S., \& Field, S. (2016). Developing the cultural awareness skills of behavior analysis. Behavior Analysis in Practice, 9, 84-94. http://dx.doi.org/10.1007/s40617-016-0111-6

[24] Fitzpatrick, J. J.(2007) Inquiry for evidence-based practice. 20 (3) 109

[25] Frels, R. K., \& Onwuegbuzie, A. J. (2012). The experiences of selected mentors: A cross-cultural examination of the dyadic relationship in school-based mentoring. Mentoring \& Tutoring, 20, 181-206.

[26] Gateshead Health NHS Foundation Trust (2010): Profile of Learning Opportunities. https://www.google.co.uk/url?sa=t\&source=web\&rct=j\&url=https://www.northumbria.ac.uk/static/5007/hces/qehw3.pdf\&ved=0ah UKEwjPxN_fnc7TAhUKZ1 AKHURACZMQFggsMAI\&usg=AFQjCNE1_A1vxvs2gXBhoyOrYWVF8dXWOw\&sig2=ioJ0axWy -WTCMuuYQYcSKQ.

[27] Godden, L., Tregunna, L., and Kutsyuruba, B. (2014),"Collaborative application of the Adaptive Mentorship model", International Journal of Mentoring and Coaching in Education, Vol. 3, No. 2, pp. 125 -140.

[28] Haggard, D.L., Turban, D.B., (2012). The mentoring relationship as a context for psychological contract development. Journal of Applied Social Psychology 42,1904-1931

[29] Hale, R. (2000). "To Match or Mis-Match? The Dynamics of Mentoring as a Route to Personal and Organizational Learning." Career Development International 5 (4/5): 223-234.

[30] Hauer, K.E., Teherani, A., Dechet, A., Aagaard, E.M., 2005. Medical students' perception ofmentoring: a focus group analysis. Medical Teacher 27 (8), 732-739.

[31] Huybrecht, S., Loeckx, W., Quaeyhaegens, Y., De Tobel, D., Mistiaen, W., 2011. Mentoring in nursing education: perceived characteristics of mentors and the consequences of mentorship. Nurse Education Today 31 (3), 274-278.

[32] Johnson, W. B. (2007). Student-faculty mentorship outcomes. In T. D. Allen \& L. T. Eby (Eds.), Blackwell handbook of mentoring (pp. 189-210). Oxford: Blackwell.

[33] Kent, A. M., Kochan, F., and Green, A.M. (2013),"Cultural influences on mentoring programs and relationships: a critical review of research", International Journal of Mentoring and Coaching in Education, Vol. 2, no. 3, pp. $204-217$.

[34] Kinnell, D. and Hughes (2010) Mentoring Nursing and Health Care Students. London: Sage Publications

[35] Koskinen, L., Tossavainen, K. (2003) Relationships with undergraduate nursing exchange students - a tutor perspective Journal of Advanced Nursing 41(5), 499-508.

[36] Kochan, F. (2013) Analyzing the Relationships between Culture and Mentoring, Mentoring \& Tutoring: Partnership in Learning, $21: 4,412-430$

[37] Kochan, F. (2002). Examining the organizational and human dimensions of mentoring:

[38] A textual data analysis. In F. Kochan (Ed.), The organizational and human dimensions of successful mentoring programs and relationships (pp. 269-286).

[39] Kram, K.E (1985), Mentoring at Work: Developmental Relationships in Organizational life, University Press of America, Lanham, MD.

[40] Leck,J., Orser, B., (2013) "Fostering trust in mentoring relationships: an exploratory study",Equality, Diversity and Inclusion: An International Journal, Vol. 32 Issue: 4, pp.410-425.

[41] Lechuga, V.M., 2011. Faculty-graduate student mentoring relationships: mentors' perceived roles and responsibilities. Higher Education 62, 757-771.

[42] Lee, S. P.; McGee, R.; Pfund, C. Branchaw, J. "Mentoring Up" (2015) Learning to Manage Your Mentoring Relationships. http://graduateschool.syr.edu/programs/graduate-school-press/ the-mentoring-continuum-from-graduate-school-through-tenure/

[43] Lipscomb, R. (2010) Practice Applications .Journal of the AMERICAN DIETETIC ASSOCIATION 110 (7), 1002-1008. 
[44] Mackey, S. (2005) Phenomenological nursing research: methodological insights derived from Heidegger's interpretive phenomenology. International Journal of Nursing Studies, Volume 42, (2), 179-186

[45] Madhavanpraphakaran, G.K., Shukri, R.K., Balachandran, S., (2014). Preceptors' perceptions of clinical nursing education. J. Contin. Educ. Nurs. 45 (1), 28-34.

[46] Maxwell, B. (2013), "Improving workplace learning of lifelong learning sector trainee teachers in the UK", Journal of Further and Higher Education, Available online at: http://www.tandfonline.com/doi/full/10.1080/0309877X.2013.831036

[47] Mayer, R.C., Davis, J.H. and Schoorman, F.D. (1995), “An integrative model of trust formation”, Academy of Management Review, Vol. 20 No. 3, pp. 709-734.

[48] McIntosh, A., Gidman, J., Smith, D., (2014). Mentors' perceptions and experiences of Supporting student nurses in practice. Int. J. Nurs. Pract. 20, 360-365.

[49] Meyer, M. (2015),"Dialectical tensions experienced by diversified mentoring dyads", International Journal of Mentoring and Coaching in Education, Vol. 4, No. 1, pp. $21-36$.

[50] Mikkonen, K., Elo, S., Tuomikoski, A.M., Kääriäinen, M. (2016) Mentor experiences of international healthcare students' learning in a clinical environment: A systematic review. Nurse Education Today (40) 87-94.

[51] Mikkonen, K., Elo, S., Kuivila, H.M., Tuomikoski, A.M., Kääriäinen, M., 2016. Culturally and linguistically diverse healthcare students' experiences of learning in a clinical environment: a systematic review of qualitative studies. Int. J. Nurs. Stud. 54, 173187.

[52] Mullen, C. A. (2007). Naturally occurring student-faculty mentoring relationships: A literature review. In T. D. Allen \& L. T. Eby (Eds.),

[53] Blackwell handbook of mentoring (pp. 119-138). Oxford: Blackwell.

[54] Newman, D., O'Reilly, P., Lee, S.H,. and Kennedy, P. (2015). Mental health service users' experiences of mental health care: an integrative literature review Journal of Psychiatric and Mental Health Nursing, 22, 171-182.

[55] Ng, P. T. (2012). Mentoring and coaching educators in the Singapore education system. International Journal of Mentoring and Coaching in Education, 1, 24-35.

[56] NHS (2007) Improvement Leader's Guide: Matching Capacity and Demand Process and System. Coventry: NHS Institute for Innovation and Improvement.

[57] NMC(2008) The Code: Standards of Conduct, Performance and Ethics For Nurses and Midwifes.London:NMC

[58] NMC (2008 b) Standards to Support Learning and Assessment in Practice. Standards for Mentors, Practice Teachers and Teachers. London: NMC.

[59] Ortiz-Walters, R., \& Gilson, L. L. (2005). Mentoring in academia: An examination of the experiences of protégés of color. Journal of Vocational Behavior, 67, 459-475.

[60] Parahoo, K. (2006) Nursing Research. Principles, Process and Issues. Hampshire: Palgrave Macmillan.

[61] Prysce, J. (2012) Mentor Attunement: An Approach to Successful School-based Mentoring Relationships. Child and Adolescent Social Work Journal. 29, 385-305.

[62] Ragins, B. R. (1997). Diversified mentoring relationships: A power perspective. Academy of Management Review, 229(2) 482-521.

[63] Rhodes, J. E. (2005). A model of youth mentoring. In D. L. DuBois \& M. J. Karcher (Eds.), Handbook of youth mentoring (pp. 3043). Thousand Oaks, CA: Sage

[64] Rhodes, J. E., Grossman, J. B., \& Rensch, N. R. (2000). Agents of change: Pathways through which mentoring relationships influence adolescent's academic adjustment. Child Development, 71, 1662-1671.

[65] Salm, T., and Mulholland, V. (2015), "Building a sustainable structure to support the Adaptive Mentorship model in teacher education", International Journal of Mentoring and Coaching in Education, Vol. 4, No. 1, pp. 53 - 68.

[66] San Miguel, C., Rogan, F., (2012). Clinical expectations: what facilitators expect from ESL students on clinical placement. Nurse Educ. Pract. 12 (2), 115-119.

[67] Shared Intelligence (2012) Phase one, Final Report: Evaluation of The Equality Delivery System (EDS) For The NHS. http://www.sharedintelligence.net/wp-content/uploads/2014/06/EDS-Final-Report-November-2012.pdf

[68] Shelmerdine,S., Louw, J (2008) Characteristics of mentoring relationships, Journal of Child \& Adolescent Mental Health, 20:1, 2132 To link to this article: http://dx.doi.org/10.2989/JCAMH.2008.20.1.5.490

[69] Wong, L. J., Wong, P. P., \& Ishiyama, F. (2013). What helps and what hinders in cross-cultural clinical supervision: A critical incident study. The Counseling Psychologist, 41, 66-85.

[70] Zachary, L. (2012), The Mentor's Guide, $2^{\text {nd }}$ ed., Jossey-Bass, San Francisco, CA. 